\title{
Phospho-specific antisera to monitor N-terminal autophosphorylation of cGMP-dependent protein kinase type I
}

\author{
Raghavan Vallur ${ }^{1,2,3^{*}}$, Hubert Kalbacher ${ }^{1}$, Jana Krauß ${ }^{1}$, Robert Feil ${ }^{1}$ \\ From 6th International Conference on cGMP: Generators, Effectors and Therapeutic Implications \\ Erfurt, Germany. 28-30 June 2013
}

\section{Background}

Although the cGMP-dependent protein kinase type I (cGKI) is an important mediator of cGMP signaling in many cells and tissues, its' in vivo-biochemistry is not well understood. It has been shown that the purified enzyme can autophosphorylate multiple sites in its $\mathrm{N}$-terminal region in the presence of ATP and cyclic nucleotides (cGMP and/or cAMP). N-terminal autophosphorylation might be involved in the activation of the kinase by cGMP in vitro, but it is not clear whether or not this also happens in intact cells [1].

\section{Results}

To detect autophosphorylated cGKI in cells and tissues, we have generated polyclonal rabbit antisera against the major in vitro autophosphorylation sites of murine cGKI-alpha (Ser-50; Thr-58, Ser-72, and Thr-84) and cGKI-beta (Thr56, Ser-63, and Ser-79). ELISAs with peptides containing the respective amino acids in their non-phosphorylated or phosphorylated form as well as Western blots with purified cGKI-alpha and cGKI-beta indicated that the antisera specifically recognized the autophosphorylated $\mathrm{N}$-termini of these isoforms. The sensitivity of detection was comparable to a highly sensitive pan-cGKI antiserum. Interestingly, the addition of ATP $(100 \mu \mathrm{M})$ alone was sufficient to induce autophosphorylation of the purified isozymes in vitro. Surprisingly, we were not able to detect phosphocGKI species in intact fibroblasts and vascular smooth muscle cells, both under basal conditions as well as after induction of cGKI kinase activity (monitored as VASP phosphorylation) with cGMP-elevating compounds.

\footnotetext{
* Correspondence: bioversatile007@gmail.com

${ }^{1}$ Interfakultäres Institut für Biochemie, University of Tübingen, Tübingen, Germany

Full list of author information is available at the end of the article
}

\section{Conclusion}

We have generated phospho-specific antisera against the $\mathrm{N}$-terminal regions of cGKI-alpha and cGKI-beta and could confirm the previously reported autophosphorylation of these isozymes in vitro. However, our results question the relevance of N-terminal autophosphorylation of cGKI in intact cells.

\section{Authors' details}

${ }^{1}$ Interfakultäres Institut für Biochemie, University of Tübingen, Tübingen Germany. ${ }^{2}$ German Center for Neurodegenerative Diseases (DZNE), Tübingen, Germany. ${ }^{3}$ Graduate School of Cellular \& Molecular Neuroscience, University of Tübingen, Tübingen, Germany.

Published: 29 August 2013

\section{Reference}

1. Francis $\mathrm{SH}$, Busch JL, Corbin JD: cGMP-dependent protein kinases and CGMP phosphodiesterases in nitric oxide and cGMP action. Pharmacol Rev 2010, 62:525-563.

\section{doi:10.1186/2050-6511-14-S1-P74}

Cite this article as: Vallur et al:: Phospho-specific antisera to monitor $\mathrm{N}$-terminal autophosphorylation of CGMP-dependent protein kinase type I. BMC Pharmacology and Toxicology 2013 14(Suppl 1):P74.

Submit your next manuscript to BioMed Central and take full advantage of:

- Convenient online submission

- Thorough peer review

- No space constraints or color figure charges

- Immediate publication on acceptance

- Inclusion in PubMed, CAS, Scopus and Google Scholar

- Research which is freely available for redistribution

\section{() Biomed Central}

(c) 2013 Vallur et al; licensee BioMed Central Ltd. This is an Open Access article distributed under the terms of the Creative Commons Attribution License (http://creativecommons.org/licenses/by/2.0), which permits unrestricted use, distribution, and reproduction in any medium, provided the original work is properly cited. 